http://kitaibelia.unideb.hu/

ISSN 2064-4507 (Online) • ISSN 1219-9672 (Print)

(C) Department of Botany, University of Debrecen, Hungary

24(1): 1-8.; 2019

DOI: $10.17542 /$ kit.24.1

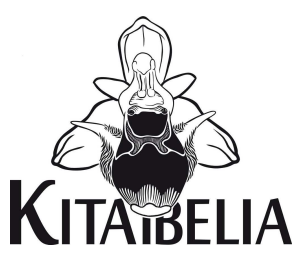

\title{
Az Apium repens császártöltési állományának monitorozása (2006-2015)
}

Kun András

H-1115 Budapest, Halmi u. 5. III/16.; kunandras29@gmail.com

Monitoring of the Apium repens population near Császártöltés (2006-2015)

\begin{abstract}
Detailed botanical surveys were carried out to monitor the population size of Apium repens in the Vörös-mocsár nature protection area (located in S Hungary, Császártöltés). We found a clear correlation between the water status and the land use type and management of the habitats and the size of the Apium repens population. Apium repens is a Nanocyperion-species, which simultaneously requires wet and open surfaces. Its population shrinks, becomes latent or disappears if its habitat dries out or any other radical transformation happens, like too much leaf litter, closure of the vegetation, or succession on the open peat surfaces. Proper management (water retention, extensive grazing, mowing, open peat surface) has a very positive effect on the populations in a short time, even within a growing season. The research was implemented within the framework of the National Biodiversity Monitoring System, in cooperation with the Kiskunság National Park Directorate.
\end{abstract}

Keywords: alluvial meadows, grazing, Kiskunság National Park, mowing, Nanocyperion, National Biodiversity Monitoring System, nature conservation management, water retention, water status

Összefoglalás - A Nemzeti Biodiverzitás-monitorozó Rendszer keretében, a Kiskunsági Nemzeti Park Igazgatóság felkérésére részletes állomány-felmérésekkel követtük nyomon az Apium repens populációméretének változásait a császártöltési Vörös-mocsár TT területén. Egyértelmú összefüggést tapasztaltunk a terület vízállapota, illetve a tájhasználat- és kezelés, valamint a növény állományának mérete között. Az A. repens iszaplakó faj, mely egyszerre igényli a nedves és nyílt felszíneket. Élőhelyének kiszáradása és átalakulása, a növényzet záródása, a tőzegfelszínek befüvesedése nyomán visszahúzódik, lappang, majd eltűnik. A megfelelő kezelésekre (vízvisszatartás, extenzív legeltetés, kaszálás, szabad tőzegfelszín nyitása) rövid idő alatt, egy tenyészidőszakon belül is pozitívan reagál.

Kulcsszavak: iszapnövény, kaszálás, Kiskunsági Nemzeti Park, kiszáradás, legeltetés, mocsárrét, NBmR, természetvédelmi kezelés, vízvisszatartás

\section{Bevezetés}

A Vörös-mocsárban 1999 szeptemberében fedeztük fel a kúszó zeller korábban ismeretlen állományát (KuN et al. 1999). A rendkívül ritka faj hazai populációinak száma az elmúlt két évtizedben tett felfedezésekkel és régi adatok megerősítésével együtt is alig több tíznél. A korábbi adatok (összefoglalásukat lásd MoLnÁr V. \& PFEIFFER 1999) és a 2000-es években történt további felfedezések alapján (északról dél felé haladva: a Szigetközben BAUER 2015, a Hanságban KIRÁLY \& KIRÁLY 2005, Vértesalján az Által-ér egykori mellékágában RIEZING 2001, az Ős-Sárvíz mentén és törmelékkúpján VoIGT 2000, FARKAS 2000, az Őrjegben, BÁTORI et al. 2014, ARADI et al. 2017) kiegészített térképek olyan faj elterjedését rajzolják ki (vö. BARTHA et 
al. 2015), amely a Duna vízgyưjtőjében a nagy folyó vizével érkezett (hydrochor termései teszik erre alkalmassá, MoLNÁR V. \& PFEIFFER 1999) és érkezik (lásd újabb megtelepedéseit a Szigetközben), majd a lápos-tőzeges medencékben, mellékfolyók mentén is terjedt. Teljes areáját tekintve atlanti-mediterrán és közép-európai elterjedésű faj, mely Dél-Spanyolországban és Marokkóban is él (DE BÉLAIR et al. 2010).

Iszapnövény lévén rendelkezik pionír karakterrel, a számára megfelelő foltokon magról megtelepszik, majd klonálisan terjed (BURMEIER \& JENSEN 2008, ROSENTHAL \& LEDERBORGEN 2008). Erre utal többek között a nagy valószínűséggel kertészeti tőzeggel történő behurcolása után a nyírott, taposott, vagy más módon zavart öntözött gyepekben való elszaporodása (például Budapesten, a Margit-szigeten - de nem kizárt, hogy ide is a Duna vizével érkezett -, PINTÉR \& BARINA 2014, BÉNDEK 2014, vagy Kiskunhalas-Kertvárosban, ARADI et al. 2017).

A Vörös-mocsár területe évezredeken át a Duna által időszakosan (évente többször is) elárasztott lápvidékhez tartozott (LÁszLóFFY 1967), az árvizek visszahúzódása után mindig lehettek olyan kisebb-nagyobb szabad felszínek, ahol az iszaplakó növények megtelepedhettek, terjedhettek. Az árvízmentesítés után már csak a legmélyebben fekvő, az oldalirányú vízáramlások (elsősorban a Duna-Tisza közi hátság területünket is határoló letörése alól kifolyó, szivárgó vizek) által nedvesen tartott, legmélyebben fekvő területeken maradtak fenn a lápvidék maradványai (RAKONCZAY 2001). Ekkor már a nyers tőzegfelszínt elsősorban a tájhasználat, illetve emberi vagy állati zavarás biztosíthatta.

A Vörös-mocsár egyedi jellemzője, hogy a korábbi (a XX. század elején megkezdődött, majd a század közepétől mind nagyobb ütemben az 1990-es évek végéig folyó) tőzegbányászat nem csupán megszüntette a mélyen fekvő lápvidék utolsó töredékeit, de a bányászat során keletkező nyílt tőzegfelszíneken kolonizálhatott, fennmaradhatott az iszapnövények néhány populációja.

A terepi megfigyelések alapján növényünk sajátos igényű: nedves és nyílt vagy felnyíló kavics- vagy tőzegfelszíneken, zsombékosok semlyékeiben képes megtelepedni. A nedves területeken a befüvesedés-becserjésedés rendkívül gyorsan, néhány év alatt végbemegy, és ilyenkor - más iszaplakókhoz hasonlóan - az Apium repens is lappang, majd állománya eltünik (pl. MolnÁR V. \& Pfeiffer 1999, VoIGT 2000, Kun \& RÉV 2012). Németországban végzett kutatások során szintén arra az eredményre jutottak, hogy mivel kompetíciós erélye gyenge, kifejezetten igényli a termőhely enyhe zavarását és optimális számára az extenzív legeltetés (ROSENTHAL \& LEDERBORGEN 2008, JENSEN et al. é.n.).

\section{Anyag és módszer}

Az Apium repens áttelelő tőlevelű, a tenyészidőszak folyamán a talaj felszínén elfekvő indákat fejlesztő növény. Az indák legyökerező szárcsomóin általában kettő-négy levél fejlődik (nem ritka az egyleveles és az ötleveles sem). Enyhén zavarástűrő, „gerilla”-stratégiájú klonális faj, ezért ha többé-kevésbé növénytelen felszínű és nedves a szubsztrátum (ez lehet mocsári semlyék, patanyom, vagy más zavarás, akár tőzegbányászat következtében keletkezett másodlagos felszín) a tavaszi levélrózsákból nyárra-őszre a klóntelepek sűrű szövedéke alakul ki (ROSENTHAL \& LEDERBORGEN 2008). Az egyes klónok (gamet) elválasztása ekkor egyszerű szemrevételezéssel már általában nem lehetséges, ezért az állományok felmérésekor a leveles szárcsomókat (ramet) számláltuk meg.

A felfedezés évében (1999) még nem végeztünk pontos állománybecslést, 2001, 2004 és 2005-ben meglátogattuk a területet és megszámláltuk az Apium repens klóntelepeit, illetve feltérképeztük a Vörös-mocsár Császártöltés határához tartozó részein a szubpopulációk elhelyezkedését. Az állomány-változások rendszeres monitorozását 2006 nyarától kezdtük meg a Kiskunsági Nemzeti Park Igazgatóság megbízásából a Nemzeti Biotiverzitás-monitoro- 
zó Program keretében. Ettől az időszaktól 5 élőhelyfolton, összesen 7 szubpopulációban évente 3 alkalommal (április, június, szeptember) végeztünk felvételezéseket. Az Apium repens-nek otthont adó 5 élőhelyfolt (a továbbiakban „élőhelyfoltok”) mindegyike a Vörösmocsár kibányászott tőzegkazettáinak közvetlen közelében, az állandó vizű tőzeges mélyedések nádas-magassásos-fúzcserjés parti zónája és homokos-löszös dombhátak közé ékelten található. Ezek a töredékes, keskeny mocsárréti sávok ma a legmélyebb fekvésű, ritkán víz alá kerülő szárazulatok, az egykor nagy kiterjedésű mocsárrétek hírmondói. Mindebből következik speciális érzékenységük: ha a vízmagasság jelentősen nő, akkor a mocsárréti növényzet eltűnik, ha csökken, akkor a zárt nádas-magassásos-füzcserjés felé való terjedésre nincs lehetőség. (Ahol a tőzeges mocsárrétek még nagy kiterjedésűek, például Sükösdnél, a szintén a Duna-völgyi főcsatorna mentén található marhalegelőkön, és oldalirányú terjedésre is van mód, ott az Apium repens több százezres állományai élnek.)

Az 5 élőhelyfolton évente egyszer (szeptemberben) teljes cönológiai felvételezést végeztünk az élőhely-változások nyomonkövetése céljából. Az élőhelyfoltokon belül kiválasztott összesen 7 Apium repens szubpopulációt és az ezeket magukba foglaló növényzetet állandósított $2 \mathrm{~m}$ sugarú $(12,56$ négyzetméteres) körlapokkal mintavételeztük (a továbbiakban „mintaterületek"). Ily módon a 10 éves felmérési periódusban összesen 29 időpont adatsora áll rendelkezésünkre (2006-ban még nem volt tavaszi felmérés). A monitorozás célja volt - a szubpopulációk sorsának nyomon követése mellett - az állományméret-változások okainak feltárása, a több négyzetkilométeres körzetben szétszórt állományok megőrzése céljából.

Az állandósított mintaterületeken megszámláltuk a kúszó zeller leveles szárcsomóit, valamint a virágzatok és magoncok számát, rögzítettünk két további adatot (levelek száma, leghosszabb levél hossza). Feljegyeztük azokat a vegetációs- és abiotikus attribútumokat is, amelyek a növény életlehetőségeit befolyásolhatják: növényzeti borítások összevont kategóriákkal, a gyepszőnyeg záródásának mértéke, a mintaterületek vízállapota (pl. víz borítja a területet / nedves / száraz a tőzeg felszíne), a növénytelen tőzegfelszínek (gap) kiterjedése, a legeltetés vagy kaszálás megtörténte (illetve ha túl mélyen történt a kaszálás), az avarosodás mértéke és a megtelepedő inváziós fajok borítása. Munkánkkal egy időben a Kiskunsági Nemzeti Park Igazgatóság munkatársai időszakos kezeléseket végeztek a területen, így ezek hatását is nyomon tudtuk követni. Felmérésünk eredményei és természetvédelmi vonatkozású következtetései részben már közlésre kerültek egy rövid összefoglalóban (KuN \& Rév 2012) és egy TDK-dolgozatban (Kun ined. in BÉNDEK 2014).

A monitorozás adattömegéből jelen munkában azokat az adatokat dolgoztuk fel, amelyek alapján kimutatható a vizsgált abiotikus és biotikus változók hatása az Apium repens populációméretére. Fő célunk, hogy rangsoroljuk a szubpopulációk méretváltozásait befolyásoló tényezőket.

\section{Eredmények}

Az 1. táblázatban a 2006-2015 között eltelt időszakban az évente 3 alkalommal felmért 7 mintaterületen élő szubpopulációk méretváltozásait, a leveles szárcsomók számlálási eredményeit mutatjuk be.

A számlálási eredmények alátámasztják a szakirodalomból is ismert, és az iszapnövényekre általában jellemző erőteljes állományméret-ingadozási és lappangási hajlamot (MoLNÁR V. \& PFEIFFER 1999, BURMEIER \& JENSEN 2008), mely az évek között és az éveken belül is megnyilvánul. Szintén általános volt a vizsgálati időszakban a populációk méretének csökkenése. A 7 mintaterület közül 2015-ben már csak kettőn fordult elő (az egyiken lappangott). Az állományméret-változásainak okait keresve a 2. táblázatban feltüntettük azokat a változókat, amelyek hatását a felmérések időpontjában rögzítettünk. 
Kitaibelia 24(1): 1-8.

1. táblázat Az Apium repens leveles szárcsomóinak száma (db) a 7 szubpopulációban (2006-2015) Szürke háttér: a leveles szárcsomók száma legalább másfélszeresére nőtt a megelőző időszakhoz képest; Sávozott háttér: a leveles szárcsomók száma legalább egyharmadával csökkent;

0: időleges lappangás; X: amikortól a növény nem került elő többé a mintaterületről

Table 1 Ramet number of Apium repens in 7 subpopulations (2006-2015)

Grey background: ramet number increased by more than $50 \%$; Striped background: ramet number decreased by more than one third; 0: not found; X: extinct

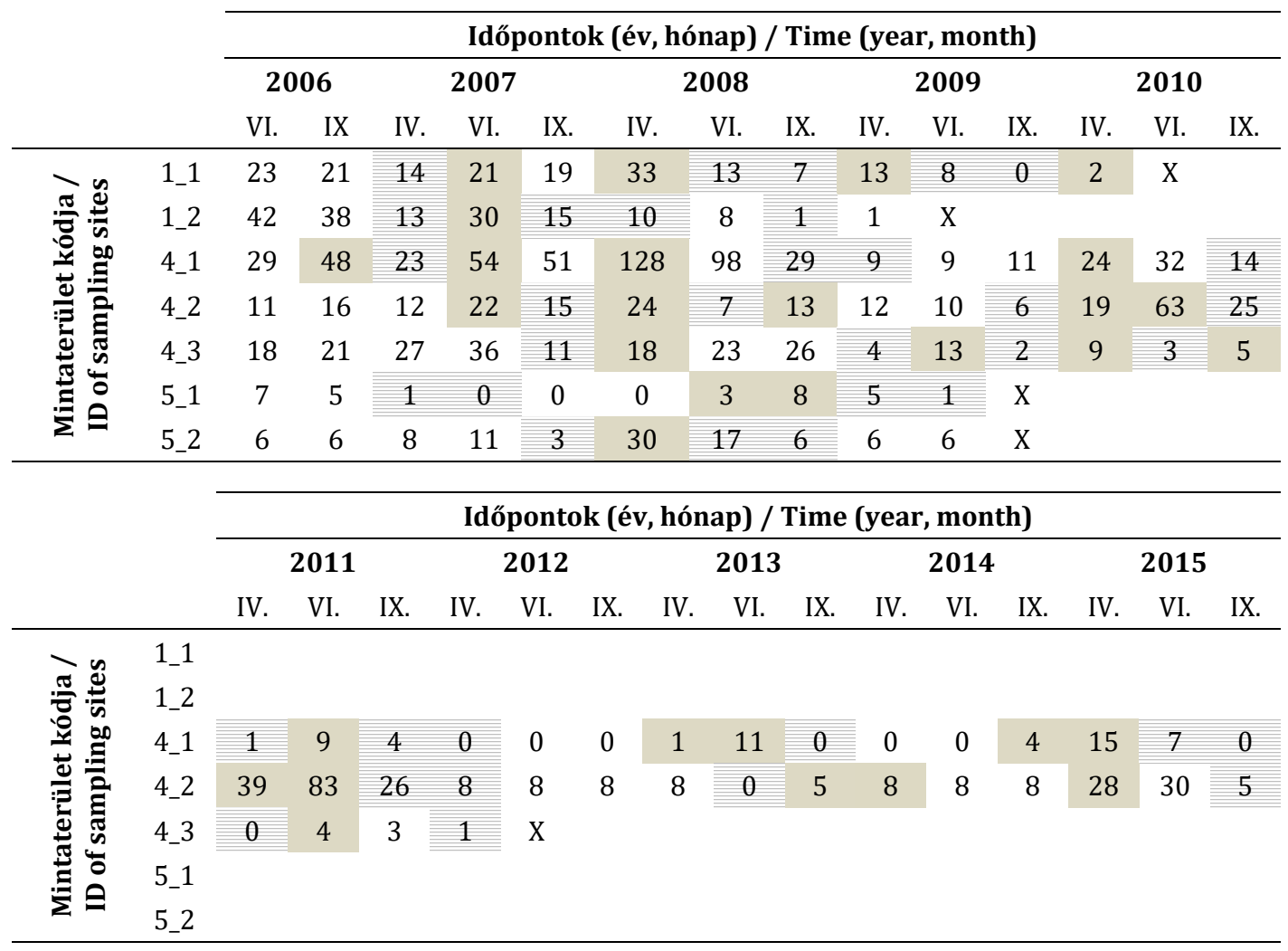

Amikor megfelelő volt a vízállapot (v), nyilt tőzegfelszín is rendelkezésre állt (g) és kaszálás is történt $(\mathrm{k})$, akkor az állomány mérete tavasztól nyárig növekedett (szürke cellák, például a 4_1 mintaterületen 2013-ban, a 4_2 mintaterületen 2010-2011-ben), de őszre ezekben az években is állománycsökkenés volt tapasztalható a nyári szárazság, záródás és az avarfelhalmozódás következtében. A két évszakon át tartó másfélszeres növekedés azonban ritka eset, gyakoribb az éven belüli és évek közötti állománycsökkenés (sávozott cellák), ami a vizsgálati időszak végére a teljes állomány erőteljes megfogyatkozását okozta.

A leveles szárcsomók számának másfélszeres, vagy nagyobb növekedését 32 alkalommal (szürke cellák az 1 . és 2. táblázatban), legalább egyharmadára történő, vagy erőteljesebb mértékű csökkenését 40 esetben tapasztaltuk (sávozással kitöltött cellák). Az ezekben a cellákban a 2. táblázatban kódokkal jelölt tényezőket a 3. táblázatban foglaltuk össze.

A tényezők között fontossági sorban első helyen áll a területek vízállapota. Amikor az Apium repens leveles szárcsomóinak száma legalább másfélszeresére nőtt, akkor a mintaterületeken többnyire (a 32 esetből 26-szor) nedves volt a tőzeg. A kiszáradással viszont 27 esetben járt együtt az állomány legalább egyharmados zsugorodása. Szintén jelentős hatású a gyep zártsága: az esetek közel felében volt pozitív eredménye a nyílt tőzegfelszínek kialakításának, amikor viszont záródott a gyep, illetve az Apium repens a felmagasodott mocsárréti növényzet alá szorult, akkor a szubpopulációk mérete csökkenni kezdett (24, illetve 25 esetben). 
2. táblázat A populációméret-változásokat előidéző fő tényezők (azonos jelölésekkel) A betűkódok magyarázata: Kedvező hatású változások, kezelések: v - vízállapot jó (tocsog a tőzeg), k - kaszálás történt, g - nyílt tőzegfelszín keletkezése (mesterséges gapnyitás, taposás), l - legeltetés. Kedvezőtlen hatású változások: $\mathrm{s}$ - gyepfolt kiszáradása, $\mathrm{z}$ - gyepszőnyeg záródása (a gyepszőnyeg és az avar eltakarja a tőzeget, az iszaplakók visszaszorulnak), a - alászorulás (a felmagasodó növényzet

árnyékot vet a nyílt tőzegfelszínekre), m - túl mély kaszálás, o - avarosodás a kaszálék otthagyása következtében (a kaszálék eltakarja a tőzeget), ai - inváziós faj (Solidago gigantea) terjedése (z, a és o hatások együttese)

Table 2. Main factors that cause changes in population size. Notations: Changes with positive effects:

$\mathrm{v}$ - wet peat, k - mowing, g - gap made, l - grazing. Changes with negative effects: $\mathrm{s}$ - drying, $\mathrm{z}$ - vegetation closure, a - shading, $\mathrm{m}$ - deep mowing, o - litter accumulation due to hay left in the area, ai - plant invasion (Solidago gigantea)

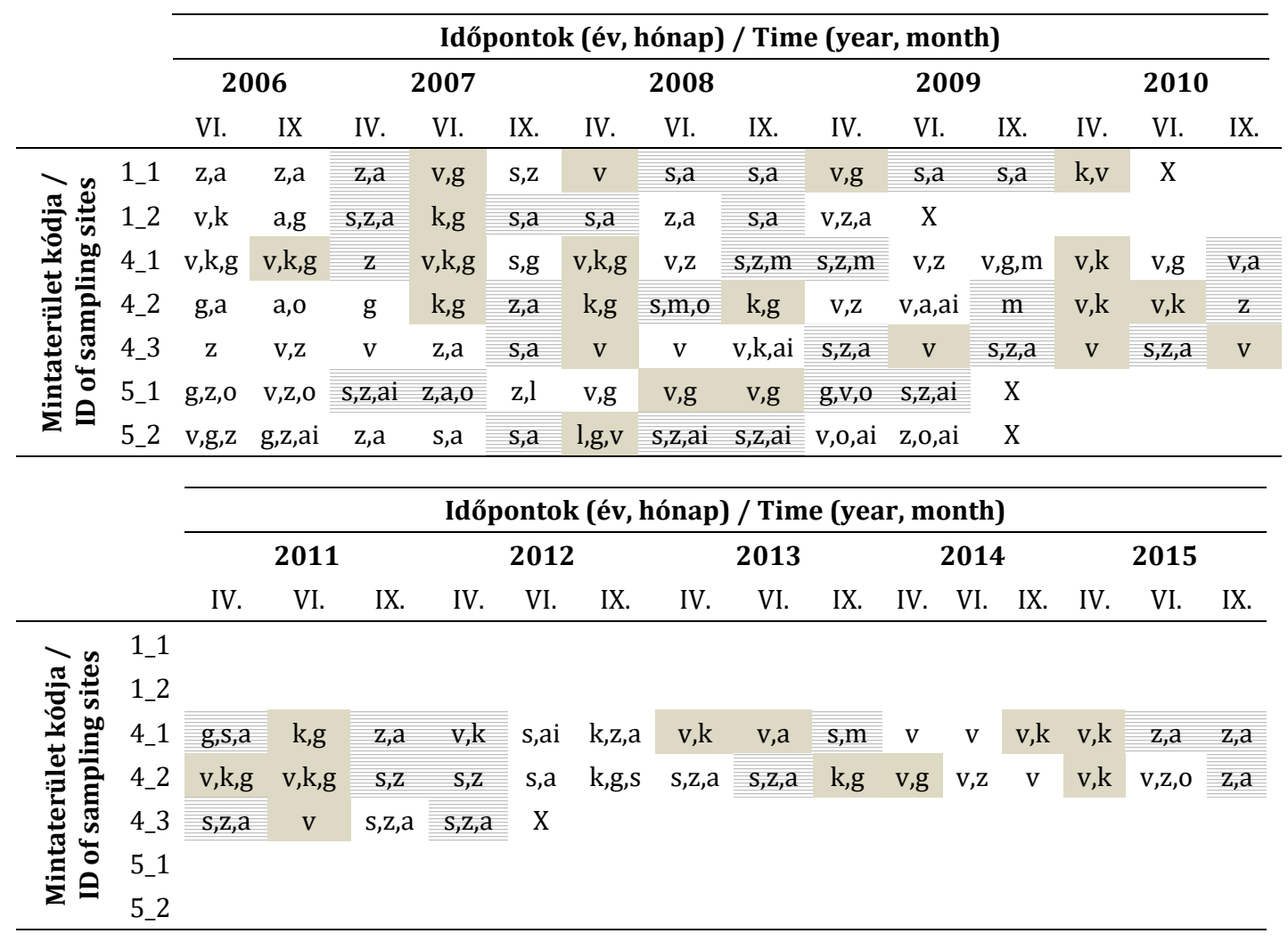

A természetvédelmi célú kaszálások (illetve egy alkalommal a legeltetés) ugyancsak pozitív hatásúak voltak (19 esetben figyeltük meg ezt), ellentétben a kaszálás elmaradásával, ami a gyep felmagasodásához vezetett (25 esetben). A túl mélyen végzett kaszálás (ami már az 5$10 \mathrm{~cm}$-es magasságú Apium repens klónokat is elérte) 5 esetben járt együtt állománycsökkenéssel, és ritkán megtörtént az is (3 eset), hogy átmenetileg a nagy mennyiségú kaszálék helyben hagyása miatt szorult vissza a növény. Mindez összefügg növényünknek azzal a mások által is leírt tulajdonságával, hogy elsődlegesen fontos számára a szabad, nedves felszínű szubsztrátum, illetve az ezt fenntartó kezelések (BURMEIER \& JENSEN 2008, JENSEN et al. é.n., ROSENTHAL \& LEDERBORGEN 2008).

Külön említendő a növényi invázió, főként a Solidago gigantea kolonizálása, ami a kiszáradással együtt az 5_1 és 5_2 mintaterületeken az Apium repens eltûnéséhez vezetett (1999ben itt fedeztük fel az első császártöltési állományát).

Fontos megjegyezni, hogy a fentebb felsorolt, populációnövekedést okozó hatások első- 
sorban a célzott természetvédelmi kezeléseknek köszönhetők. Kutatásaink nyomán évről-évre tervezett beavatkozások folytak a területen: vízvisszatartás, kaszálás és a tőzegfelszín kijelölt helyszíneken történt mesterséges megsértése. Mint láttuk, a növény visszaszorulásában legfőbb tényező a kiszáradás: a kedvezőtlen csapadékjárású időszakban a természetvédelmi szakemberek folyamatos munkája sem hozta meg a kívánt eredményt. Bár a szubpopulációk két ponton fennmaradtak, az általános csökkenési tendenciát nem sikerült megfordítani.

3. táblázat A változásokat előidéző tényezők jelentősége

Table 3 The importance of main factors

Az A. repens populációnövekedése szempontjából... / Effect on the population size of $A$. repens

kedvező (másfélszeres növekedés, kedvezőtlen (egyharmados összesen 32 esetben) / csökkenés, összesen 40 esetben) / positive (ramet number increased negative (ramet number decreased by by more than $50 \%$; in 32 cases) more than one third; in 40 cases)

\begin{tabular}{|c|c|c|}
\hline $\begin{array}{l}\text { Mintaterület } \\
\text { vízállapota / } \\
\text { water status }\end{array}$ & $\begin{array}{l}\text { nedves a tőzeg } \\
\text { ( } 26 \text { eset) / } \\
\text { wet peat ( } 26 \text { cases) }\end{array}$ & $\begin{array}{l}\text { kiszáradás ( } 27 \text { eset) / } \\
\text { drying ( } 27 \text { cases })\end{array}$ \\
\hline \multirow{2}{*}{$\begin{array}{l}\text { Gyep záródása / } \\
\text { closure of the } \\
\text { vegetation }\end{array}$} & \multirow{2}{*}{$\begin{array}{l}\text { nyílt tőzegfelszín megfigyelhető } \\
\text { (17 eset) / } \\
\text { open peat surfaces ( } 17 \text { cases) }\end{array}$} & $\begin{array}{l}\text { felmagasodik a gyep } \\
\text { (alászorulás, } 25 \text { eset) / } \\
\text { shading ( } 25 \text { cases) }\end{array}$ \\
\hline & & $\begin{array}{l}\text { záródik a gyep ( } 24 \text { eset) / } \\
\text { vegetation closure ( } 24 \text { cases) }\end{array}$ \\
\hline \multirow{2}{*}{$\begin{array}{l}\text { Kezelés, } \\
\text { agrotechnika / } \\
\text { management }\end{array}$} & $\begin{array}{l}\text { kaszálás (19 eset) / } \\
\text { mowing ( } 19 \text { cases) }\end{array}$ & $\begin{array}{l}\text { mélykaszálás ( } 5 \text { eset) / } \\
\text { deep mowing ( } 5 \text { cases) }\end{array}$ \\
\hline & $\begin{array}{l}\text { legeltetés ( } 1 \text { eset) / } \\
\text { grazing ( } 1 \text { case) }\end{array}$ & $\begin{array}{l}\text { kaszálék helyben hagyása ( } 3 \text { eset) / } \\
\text { litter accumulation due to hay left in the } \\
\text { area ( } 3 \text { cases) }\end{array}$ \\
\hline $\begin{array}{l}\text { Növényi invázió / } \\
\text { plant invasion }\end{array}$ & & Solidago gigantea ( 4 eset) / ( 4 cases) \\
\hline
\end{tabular}

\section{További terepi megfigyelések}

A császártöltési Apium repens szubpopulációk 1999 és 2004 között kivétel nélkül Agrostis stolonifera által dominált, foltokban nádasodó, rekettyefúzzel cserjésedő mocsárréteken fordultak elő (Kun et al. 1999). Ebben az időszakban még rendszeresen láttunk legelő teheneket a vizsgált állományokban. Megfigyeltük, hogy az extenzív legeltetés (0,5-1 számosállat/ha) megfelelő vízállapot esetén kedvező a növénynek, a nedves tőzegen terjedt, számos magonca fejlődött a patanyomok kis lékeiben (néhol a horgászati célú gilisztaásók nyomain és keréknyomokban is).

Későbbiekben a területről eltűntek a legelő állatok, a gyepek záródtak, felmagasodtak, egyes állományok cserjésedésnek, mások nádasodásnak indultak. Ennek következtében és az általános kiszáradás miatt az Apium repens szubpopulációi zsugorodni kezdtek. Az Agrostisgyep viszonylag laza szövedékében esetenként több évig lappangott (lásd az 1. táblázatban), ám ahol a szukcesszió tovább folyt és a nagytermetű domináns fajok (Juncus inflexus, Phragmites australis) kolonizáltak, fokozatosan alászorult. A lappangás több évszakon át - erre példa a 4_1 mintaterület -, de akár évekig is tarthat. Utóbbira példa az a mintaterületeken kívül eső populáció, amely 2001-ben még több tucat klónt számlált, de a terület teljes benádasodása és cserjésedése következtében 2010-re már lappangott. 2011-től természetvédelmi célú cserjeirtások-kaszálások kezdődtek a foltban, majd 2014-ben újra megtaláltuk a növény 
néhány példányát, és a rendszeres kaszálások következtében a szubpopuláció kismértékű növekedést mutatott. Másik, ugyancsak mintaterületen kívül eső Apium repens szubpopuláció számára a teljes becserjésedés (Salix cinerea, S. purpurea) végzetesnek bizonyult.

\section{Következtetések}

Az Apium repens évelő iszapnövény, mely egyszerre igényli a szabad és nedves felszínű szubsztrátumot (területünkön ez a tőzeg, a Szigetközben homok és kavics). Ha e két feltétel közül valamelyik hiányzik, akkor visszaszorul, lappang, majd eltűnik. Ha élőhelyén a tőzegfelszín nedves, és kismértékủ zavarás következtében gátolt a növényzet záródása, felmagasodása, akkor nyár közepére erőteljesen kolonizál (nem ritkán szőnyegszerűen). Gyorsan, éven belül is pozitívan reagál tehát a megfelelő irányú változásokra.

Felmérésünk eredményei azt mutatják, hogy az állományméret fennmaradásának, növekedésének elsődleges feltétele az üde termőhely (nedves tőzeg, talajvízszint a felszín közelében). Ennek hiányában a kaszálás és a nyílt tőzegfelszínek biztosítása sem képes fenntartani az Apium repens számára kedvező állapotot.

\section{Köszönetnyilvánítás}

A felmérések a Nemzeti Biodiverzitás-monitorozó Program keretében folytak. Köszönöm Kovács Évának (KNPI) a természetvédelmi szakmai háttér és a munkafeltételek biztosítását, folyamatos segítségét és a kézirat javító átnézését. Rév Szilviának a terepi felmérések során nyújtott segítségért és a kézirat javításáért mondok köszönetet. Illesse köszönet a kézirat lektorait, akik munkámat értékes meglátásokkal segítették.

\section{Irodalom}

ARAdi E., ERdős L., Cseh V., TöLGyesi Cs. \& BÁtori Z. (2017): Adatok Magyarország flórájához és vegetációjához II. - Kitaibelia 22(1): 104-113.

Bartha D., Király G., Schmidt D., Tiborcz V., Barina Z., Csiky J., JakAB G., Lesku B., SchmotZer A., Vidéki R., Vojtкó A. \& Zólyomi Sz. (szerk.) (2015): Magyarország edényes növényfajainak elterjedési atlasza. Nyugat-magyarországi Egyetem Kiadó, Sopron.

BAUER N. (2015): Az Apium repens (Jacq.) Lagasca új előfordulása a Szigetközben. - Kitaibelia 20(2): 300.

BÁtori Z., ERdős L., CSEH V., Tölgyesi Cs. \& ARADi E. (2014): Adatok Magyarország flórájához és vegetációjához I. - Kitaibelia 19(1): 89-104.

BÉLAIR DE G., BAGELLA S. \& RHAZI L. (2010): Apium repens. The IUCN Red List of Threatened Species 2010: e.T161949A5517734. Downloaded on 7 October 2018.

BÉNDEK J. (2014): A védett kúszó zeller (Apium repens) társulási viszonyai és megőrzésének lehetôségei mesterséges élőhelyen. TDK dolgozat. Szent István Egyetem, Mezőgazdaság- és Környezettudományi Kar, Természetvédelmi és Tájgazdálkodási Intézet. Gödöllő. 44 pp.

BuRMEIER S. \& JENSEN K. (2008): Is the endangered Apium repens (Jacq.) Lag. rare because of a narrow regeneration niche? - Plant Species Biology 23(2): 111-118.

FARKAS S. (2000): A kúszó zeller [Apium repens (Jacq.) Lagasca] új előfordulása a Tolnai-Sárközben. Kitaibelia 5(2): 370.

Jensen K., SCHWERdTFeger J. \& BuRMeier S. (é.n.): Conservation guidelines for Apium repens. Universitat Hamburg. 45 pp. https://www.life-baltcoast.de/fileadmin/user_upload/Conservation_guideline_ Apium_repens-05_04_11.pdf

KIRÁLY G. \& KIRÁLY A. (2005): Adatok és kiegészítések a magyar flóra ismeretéhez II. - Kitaibelia 10(1): 88-103.

Kun A., AszaLós R., CSECSERITS A. \& RÉDEI T. (1999): A kúszó zeller [Apium repens (Jacq.) Lagasca] előfordu- 
lása Császártöltés mellett. Néhány adat a Duna-Tisza közének flórájához. - Kitaibelia 4(2): 227-228.

Kun A. \& RÉv Sz. (2012): Az Apium repens (Jacq.) Lagasca császártöltési állományának monitorozása (2006-2011). Javaslatok a természetvédelmi kezelésre. - Kitaibelia 17(1): 111.

LÁSZLófFy W. (1967): Felszíni vízfolyások. - In: PÉcsi M. (szerk.), A dunai Alföld. Akadémiai Kiadó, Budapest, pp. 184-199.

MolnÁR V. A. \& Pfeiffer N. (1999): Adatok hazai Nanocyperion-fajok ismeretéhez II. - Kitaibelia 4(2): 391-421.

PintéR B. \& BARinA Z. (2014): Az Apium repens (Jacq.) Lagasca Budapesten. - Kitaibelia 19(2): 365.

RAKONCZAY Z., TÖLGYESI I. \& VAJDA Z. (2001): Császártöltési Vörös-mocsár TT. - In: RAKonCzAY Z. (szerk.), $A$ Kiskunságtól Bácsalmásig. Mezőgazda Kiadó, Budapest, pp. 263-266.

Riezing N. (2001): Ophrys apifera Huds. és Apium repens (Jacq.) Lagasca előfordulása a Vértesben. Kitaibelia 6(2): 371-375.

Rosenthal G. \& Lederbogen D. (2008): Response of the clonal plant Apium repens (Jacq.) Lag. to extensive grazing. - Flora 203: 141-151.

Voigt W. (2000): Az Apium repens (Jacq.) Lagasca új előfordulása Pakson. - Kitaibelia 5(1): 87-92.

Beérkezett / received: 2018. 10.17. • Elfogadva / accepted: 2019. 02. 14. 